\title{
ANALISIS KASUS KANKER LIDAH DALAM KONTEKS ASUHAN KEPERAWATAN DENGAN PENDEKATAN COMFORT THEORY MODEL
}

\author{
Analysis of inventory cancer case in context of nursing assessment \\ With comfort theory model approach
}

\author{
Dewi Nurviana Suharto \\ Poltekkes Kemenkes Palu \\ (dewinurviana.suharto@gmail.com, 0811459788)
}

\begin{abstract}
ABSTRAK
Prevalensi pasien dengan kanker setiap tahun terus mengalami peningkatan. Kanker lidah merupakan keganasan jenis karsinoma yang mengenai lidah dan hampir 95\% berupa karsinoma sel skuamosa. Kanker lidah merupakan kanker dengan progresifitas yang tinggi dengan prognosis jelek sehingga angka kematiannya akibat kanker lidah sangat tinggi serta menimbulkan ketidaknyaman. Kenyamanan merupakan titik pangkal dari berbagai kesembuhan yang akan dicapai oleh klien. Perbaikan kondisi klien tidak akan dicapai jika kebutuhan akan rasa nyaman tidak terpenuhi. Dalam pemberian asuhan keperawatan masalah yang muncul pada kanker lidah adalah nyeri kronis, ketidakseimbangan nutrisi kurang dari kebutuhan tubuh dan ketidakefektifan pola napas. Analisis proses praktik residensi menunjukkan bahwa comfort theory dapat diterapkan pada pasien dengan kasus keganasan dalam pemberian asuhan keperawatan, karena mampu mengidentifikasi ketidaknyaman pasien secara holistik dari aspek fisik, psikospiritual, sosiokultural dan lingkungan.
\end{abstract}

\section{Kata kunci : Comfort Theory, Kanker Lidah}

\section{ABSTRACT}

The prevalence of patients with cancer increase every year. Tongue cancer is a type of malignancy of the tongue, and almost $95 \%$ is squamous cell carcinoma. Tongue cancer is a cancer with high progression with bad prognosis so that the mortality rate is very high and often causes discomfort. Comfort is the starting point of various healing that will be achieved by the client. Improvements in client conditions will not be achieved if the need of comfort is not fulfilled. In nursing care the problems that arise in tongue cancer are chronic pain, nutrient imbalance: less than body needs, and ineffective breathing patterns. Analysis of residency practice processes shows that comfort theory can be applied to patients with malignancy cases in nursing care, as it can identify patients' holistic discomfort from the physical, psychospiritual, sociocultural and environmental aspects.

\section{Keyword : Comfort Theory, Tongue Cancer}

\section{PENDAHULUAN}

\section{Kanker lidah merupakan keganasan} jenis karsinoma yang mengenai lidah dan hampir 95\% berupa karsinoma sel skuamosa. Insiden dan mortalitas kanker lidah bervariasi tergantung dari area geografis ${ }^{(1)}$. Secara geografis, India menunjukkan tingkat kejadian kanker rongga mulut yang tinggi yaitu sebesar 7,5 per 100.000 penduduk dan menyebabkan beban kesehatan utama $^{(2)}$. Sedangkan di indonesia kanker lidah merupakan kasus yang jarang terjadi, data dari Instalasi Deteksi Dini dan Promosi Kesehatan RS Kanker Dharmais (2010-2013) Insiden kanker lidah termasuk masih jarang, kejadiannya hanya sekitar $14 \%$ dari semua jenis kanker yang dirawat ${ }^{(3)}$. Namun kanker lidah merupakan kanker 
dengan progresifitas yang tinggi dengan prognosis yang jelek sehingga angka kematian pada pasien yang dirawat akibat kanker lidah sangat tinggi.

Kanker lidah lebih sering terjadi pada kelompok usia yang lebih tua yaitu usia 40 tahun ke atas, meskipun dapat ditemukan pada orang muda. Kanker ini dua kali lebih umum pada pria dari pada wanita $^{(2)}$. Faktor utama yang berperan terhadap timbulnya karsinoma lidah adalah penggunaan tembakau dan alkohol dalam jangka waktu lama. Faktor lain adalah infeksi virus papiloma dan faktor kebersihan gigi serta mulut ${ }^{(1)}$. Gejala kanker lidah berupa bercak merah atau putih pada lidah yang tidak bisa hilang, sakit tenggorokan yang lama, munculnya ulkus atau benjolan di lidah yang tidak hilang, nyeri saat menelan dan mati rasa di mulut. Gejala yang sangat umum menyebabkan penyakit ini terdiagnosis pada stadium lanjut, sehingga pilihan pengobatan menjadi terbatas, prognosis jelek dan kelangsungan hidup relatif singkat ${ }^{(4)}$.

Pengobatan untuk kanker lidah tergantung pada ukuran kanker. Pengobatan untuk kanker lidah stadium dini adalah operasi. Untuk tumor yang lebih besar dan telah menyebar ke kelenjar getah bening di leher, yaitu kombinasi operasi dan radioterapi ${ }^{5}$. Pengobatan yang dilakukan pada stadium dini dapat meningkatkan kelangsungan hidup pasien mencapai 5 tahun dan angkan kelangsungan hidup kurang dari 1 tahun terjadi pada pasien dengan stadium lanjut ${ }^{(6)}$. Pada stadium lanjut pengobatan bukan lagi ditujukkan untuk menyembuhkan tapi lebih kepada pengobatan untuk mengurangi gejala dan meningkatkan kualitas hidup pasien ${ }^{(2)}$.

Salah satu peran perawat spesialis dalam pengelolaan kasus dan sesuai dengan perawatan paliatif adalah comfort care. Kenyamanan merupakan titik pangkal dari berbagai kesembuhan yang akan dicapai oleh klien. Perbaikan kondisi klien tidak akan dicapai jika kebutuhan akan rasa nyaman tidak terpenuhi. Oleh karena itu rasa nyaman sifatnya holistik dan sangat individual mencakup physical, psychospiritual, enviromental dan sociocultural ${ }^{(7)}$. Tugas perawat untuk memenuhi kebutuhan akan rasa nyaman yang sifatnya holistik tersebut. Seorang perawat spesialis harus dapat mengidentifikasi kebutuhan kenyamanan yang tidak terlihat dari pasien, dan bersifat subyektif. Kondisi pasien kanker yang sebagian besar mengalami nyeri dan ketidaknyaman, sehingga peran tersebut dapat diaplikasikan dengan menggunakan comfort teory model.

\section{GAMBARAN KASUS}

Seorang pasien wanita (Ny. SJ) usia 25 tahun, agama islam, status menikah, pendidikan SLTA, pekerjaan karyawan swasta, dengan alamat di jalan Bango, Tangerang, nomor medikal record 219276. Diagnosa medis Pleomorphic high grade sarcoma, grade 3 (FNCLCC) karsinoma lidah berdiferesiasi buruk.Pengkajian dilakukan tanggal 15 Februari 2017 klien nampak sangat lemah, pucat dan tidak bertenaga. Sejak 2 bulan yang lalu klien sudah tidak bisa bicara kanker kanker lidah sudah memenuhi rongga mulut klien. Klien terpasang trakheostomi, produksi lendir banyak, batuk, terpasang oksigen melalui trakheostomi 5 liter permenit (LPM). Terpasang gastrostomi pada perut sebelah kiri, intake nutrisi melalui gastrostomi, klien mengalami penurunan berat badan dalam 6 bulan terakhir sekitar $25 \mathrm{Kg}$. BB klien sebelumnya $65 \mathrm{Kg}$, BB saat ini $40 \mathrm{Kg}$, TB 
$158 \mathrm{CM}$, IMT : $16 \mathrm{Kg} / \mathrm{m} 2$ (Underweight). Mukosa bibir kering dan pecah-pecah, terdapat luka invasi kanker pada dagu tertutup kasa, terdapat rembesan pada kasa, luka diganti setiap pagi dan sore. Dileher kiri klien terdapat luka kanker yang mengeluarkan cairan berwarna kekuningan, luka tertutup kasa tebal, terlihat rembesan pada kasa. Klien nampak meringis karena merasa nyeri pada luka setiap diganti balutan, nyeri skala 5 , nyeri hilang timbul, nyeri seperti ditusuk-tusuk.

Hasil pemeriksaan fisik : tekanan darah 140/90 mmHg, frekuensi nadi 68 kali per menit, nadi lemah dan teratur, frekuensi napas 24 kali per menit, irama tidak teratur. Konjungtiva terlihat anemis dan mukosa bibir kering. Klien menggunakan otot bantu napas, vokal fremitus kiri menurun, trill $(+)$, perkusi paru pekak pada lapang paru kiri, suara napas menurun pada lapang paru kiri, terdengar bunyi ronki. Capillary refill time 3 detik, turgor kulit sedang, kulit nampak kering dan terkelupas, pada area lengan bawah sebelah kanan dan kiri terdapat petekie. Klien terlihat kurus, intake nutrisi melalui gastrostomi diet cair 1200 Kkal dengan pemberian 6 X 200cc. Hasil pemeriksaan laboratorium diperoleh hemoglobin $10.9 \mathrm{~g} / \mathrm{dL}$ (normal/N= 13-18), leukosit 16.95 $10^{3} / \mathrm{uL}(\mathrm{N}=5-10)$, trombosit $14310^{3} / \mathrm{uL}(\mathrm{N}=150$ $440)$, eritosit $3.9110^{6} / \mathrm{uL}(\mathrm{N}=4,6-6,2)$, hematokrit $31.4 \%(\mathrm{~N}=40-45)$, MCV 80.3 fL ( $\mathrm{N}=90-100)$, Absolute Neutrofil Count 16.13 103/uL (2.50-7.00). Klien mendapatkan terapi herbeser 13 mikro tiap 12 jam secara intravena melalui syringe pump, vitamin $\mathrm{K} 10 \mathrm{mg}$ dalam $\mathrm{NaCl}$ 0,9\% $100 \mathrm{cc}$ tiap 8 jam, KCL 12,5 mg dalam Nacl 0,9\% tiap 6 jam secara intravena, infus aminofluid + soluvn + vitalipid tiap 24 jam, MO $15 \mathrm{mg}$ dalam $\mathrm{NaCl}$ 0,9\% 50 cc tiap 6 jam menggunakan syringe pump.
Klien juga mendapatkan terapi nebulizer jika dibutuhkan.

\section{METODE PENELITIAN}

Penulisan karya ilmiah ini menggunakan metode studi kasus, yaitu analisis penerapan asuhan keperawatan pada kasus kanker lidah. Adapun teknik pengumpulan data yang digunakan meliputi wawancara, observasi, catatan individu, atau rekam medik dan perawatan. Data yang telah terkumpul dianalisis untuk melihat masalah keperawatan yang dialami klien serta meninjau keefektifan intervensi yang telah dilakukan untuk menyelesaikan masalah keperawatan pasien.

\section{HASIL}

Pengkajian yang dilakukan ditemukan beberapa masalah keperawatan yang terjadi diantaranya nyeri kronis, ketidakseimbangan nutrisi kurang dari kebutuhan tubuh, ketidakefektifan pola napas.

Nyeri kronik. Data yang berhubungan yaitu keluhan nyeri pada area luka invasi massa kanker di area dagu dan leher sebelah kiri, nampak menonjol keluar. Skala nyeri 5, nyeri hilang timbul, nyeri seperti ditusuk-tusuk, nyeri dirasakan sejak 6 bulan yang lalu, nyeri memberat jika balutan diganti. Tindakan yang diberikan pada pasien adalah manajemen nyeri yang bertujuan untuk mengontrol nyeri pasien.

\section{Ketidakseimbangan nutrisi kurang dari}

kebutuhan tubuh. Data yang berhubungan sejak 2 bulan terakhir klien tidak bisa lagi makan dan minum melalui oral, terpasang gastrostomi diperut sebelah kiri, BB klien sebelumnya $65 \mathrm{Kg}$, BB saat ini $40 \mathrm{Kg}$, TB $158 \mathrm{CM}$, IMT : $16 \mathrm{Kg} / \mathrm{m} 2$ (Underweight). Tindakan yang diberikan pada 
pasien adalah manajemen nutrisi yang bertujuan untuk meningkatkan intake nutrisi makanan dan minuman serta status mikro nutrien

Ketidakefektifan pola nafas. Data yang berhubungan batuk berlendir, produksi sekret banyak, terpasang trakheostomi, terpasang oksigen 5 LPM. Klien menggunakan otot bantu napas, vokal fremitus kiri menurun, trill (+), perkusi paru pekak pada lapang paru kiri, suara napas menurun pada lapang paru kiri, terdengar bunyi ronki. Tindakan yang diberikan pada pasien adalah Respiratory Monitoring dan Oxygen Therapy yang bertujuan untuk meningkatkan status respirasi pasien.

\section{PEMBAHASAN}

Hasil pengkajian pasien diketahui faktor resiko penyebab munculnya kanker lidah adalah inflamasi atau iritasi kronis pada rongga mulut. Kanker ganas lidah timbul pada tempat yang sesuai dengan sumber iritasi kronik seperti caries gigi atau gigi busuk dengan calculus yang banyak, dan juga karena pemasangan gigi palsu atau prothesa yang posisinya tidak $\operatorname{cocok}^{(8,9,10)}$. Penelitian lain juga melaporkan bahwa pada pasien kanker lidah yang dirawat memiliki riwayat kebersihan mulut yang buruk, pemakaian behel gigi yang lama, caries gigi dan penggunaan gigi palsu $^{(11)}$ Dari hasil pengkajian pasien tidak memiliki riwayat merokok dan minum alkohol.

Gejala ketidaknyamanan yang pertama kali dirasakan oleh NY. SJ adalah munculnya lesi dilidah yang terus menerus dan tidak sembuhsembuh sampai akhirnya berubah menjadi ulkus. Dari hasil pemeriksaan MSCT Scan Nasofaring, terdapat lesi lingual kiri sisi posterior yang melibatkan orofaring sugestif maligna. Kanker lidah terbanyak adalah pada bagian lateral termasuk pada pasien yang awal mula munculnya lesi pada bagian lateral. Hasil studi juga melaporkan bahwa sebagian besar kanker lidah muncul pada bagian lateral sebesar $85 \%$, pada bagian dorsum sebesar $5 \%$, permukaan lidah sebesar 5\% dan ujung lidah sebesar 5\% ${ }^{12}$. Hasil pemeriksaan juga menunjukkan adanya keterlibatan kelenjar getah bening regional dan infiltrasi dengan gambaran MSCT scan yaitu limfadenopati multiple perijugular bilateral dan submandibula bilateral dengan kecurigaan adanya infiltrasi ke vena jungularis kiri. Studi yang dilakukan pada 57 pasien kanker lidah menggambarkan bahwa kanker lidah memiliki prognosis yang buruk karena tingginya angka metastasis ke kelenjar getah bening regional ${ }^{(13,14)}$, serta invasi tumor ke area lokal ${ }^{(15)}$.

Nyeri. Pengkajian keperawatan berdasarkan comfort theory, dilakukan untuk mengidentifikasi ketidaknyamanan yang muncul. Pengkajian pada tahap relief ditemukan nyeri kronis berada pada skala sedang, nyeri memberat saat ganti balutan. Nyeri yang dirasakan pasien merupakan efek dari kerusakan jaringan yang aktual sehingga menyebabkan munculnya sensori dan emosional yang tidak menyenangkan ${ }^{(16,17)}$. Perubahan pada vital sign akibat nyeri yaitu TD 140/90 mmHg, RR : 28x/mnt dan nadi 100x/mnt. Nyeri merupakan respon subyektif, sehingga pengkajian berfokus pada respon subyektif serta fisik yang terlihat dari pasien. Pada tahap ease, pasien diharapkan mampu untuk mengontrol nyeri yang dirasakan atau yang muncul. Kondisi pasien dengan perawatan paliatif dan dengan kanker stadium lanjut akan menimbulkan nyeri yang hebat akibat invasi kanker, sehingga dalam mengontrol 
nyeri membutuhkan penanganan kolaborasi dengan memberikan analgesik untuk mengurangi nyeri yaitu pemberian MO $15 \mathrm{mg}$ pada pasien. Pada tahap transcendence, perawat menyiapakan untuk meningkatkan kenyamanan pasien. pasien dengan kanker lidah akan menimbulkan berbagai ketidaknyamanan akibat nyeri. terlihat pada pasien nyeri menyebabkan pasien takut untuk bergerak, pasien kesulitan tidur dan pasien merasa kelelahan. Tindakan yang diberikan yaitu dengan membantu pasien untuk merubah posisi serta memberikan posisi yang nyaman untuk mengurangi nyeri, memberikan massage ringan pada area ekstremitas untuk memberikan kenyamanan agar meningkatkan fase istirahat dan mengurangi kelelahan.

\section{Ketidakseimbangan nutrisi. Nutrisi} merupakan masalah keperawatan yang erat kaitannya dengan kanker, manajemen nutrisi yang baik sangat penting untuk kelangsungan hidup pasien kanker. Pengkajian pada tahap relief ditemukan klien mengalami penurunan berat badan dalam 6 bulan terakhir sekitar $25 \mathrm{Kg}$. BB klien sebelumnya $65 \mathrm{Kg}$, BB saat ini $40 \mathrm{Kg}$, TB $158 \mathrm{CM}$, IMT : $16 \mathrm{Kg} / \mathrm{m} 2$ (Underweight), klien terlihat kurus dan nilai hemoglobin $10.9 \mathrm{~g} / \mathrm{dL}$. Nutrisi merupakan masalah ketidaknyamanan yang paling sering muncul pada pasien kanker rongga mulut terutama kanker lidah. Perkembangan kanker lidah yang progresif, cepat dan berdiferensiasi buruk menyebabkan kanker ini menutup akses makanan melalui oral, kondisi ini yang menyebabkan terjadinya kaheksia pada pasien dengan kanker lidah. Pada tahap ease, perawat diharapkan mampu untuk menghitung kebutuhan kalori harian yang diperlukan pasien untuk memenuhi nutrisinya. Hasil perhitungan pasien membutuhkan 2000 kkal setiap hari, dengan pemberian diet cair 200cc sebanyak 5 kali permberian setiap hari. Pada tahap transcendece, tindakan yang diberikan untuk meningkatkan kenyamanan yaitu kolaborasi untuk tindakan gastrostomy, mengingat intake nutrisi tidak bisa melalui orang dan beresiko perdarahan jika menggunakan NGT karena kanker hampir menutupi area esofagus. Untuk pemberian nutrisi melalui gastrostomy, perawat melakukan edukasi dan mengajar cara pemberian nutrisi melalui gastrostomy pada keluarga selama perawatan pasien, hal ini bertujuan untuk memandirikan keluarga saat perawatan tidak lagi dilakukan di rumah sakit. Selain itu hal penting yang perlu diperhatikan juga adalah perawatan gastrostomy untuk menghindari terjadinya infeksi. Perawatan gastrostomy dilakukan dengan mengganti balutan setiap 3 hari sekali, mengatur posisi gastrostomy untuk menghindari gastrostomy terlipat atau tertarik. Tindakan kenyamanan yang kongkrit dan sesuai dengan kondisi pasien dapat meningkatkan kenyamanan pasien kanker lidah.

Ketidakefektifan pola nafas adalah pertukaran udara inspirasi dan/atau ekspirasi tidak adekuat (18). Pengkajian pada tahap relief, ditemukan sesak napas, pernapasan 28x/mnt, batuk berlendir, terdapat bunyi ronchi, penggunaan otot bantu pernapasan, $\mathrm{Sa} 02$ 98\% dan capilary refilling time 3 detik. Kondisi ini sesuai dengan gambaran penyakit pasien dimana telah terjadi metastasis ke paru. Gambaran foto toraks Ny. SJ (Tgl 27-012017) ditemukan efusi pleura kiri dan nodul multiple pada paru kanan. Efusi pleura muncul sebagai efek dari metastasis tersebut. Efusi pleura secara akan menyebabkan pasien sesak dan kesulitan bernapas. Hal ini akan memunculkan ketidaknyamanan pada pasien kanker lidah yang 
akan mempengaruhi outcame pasien. Pada tahap ease, perawat berusaha untuk mengurangi ketidaknyamanan pasien dengan melakukan suction pada trakheostomi untuk mengurangi akumulasi lendir pada jalan napas, mengganti balutan trakheostomi setiap hari, mempertahankan kelembapan udara melalui trakheostomi dan mengganti kanul trakheostomi jika setiap hari. Tahap transcendece dipenuhi untuk meningkatkan kenyamanan pasien kanker lidah, ketidaknyamanan muncul akibat sesak napas, maka dilakukan tindakan kolaborasi pemberian oksigen $5 \mathrm{ltr} / \mathrm{mnt}$ melalui trakheostomi untuk mencukupi kebutuhan oksigen pasien. Terapi oksigen sangat penting diberikan untuk menjamin kecukupan oksigen terutama pada pasien kanker lidah. Namun, pada pasein kanker dengan stadium lanjut dan metastasis paru terapi oksigen hanya merupakan terapi pendukung untuk mengurangi kenyamanan pasien, karena masalah utama bersumber dari paru, dan memerlukan tindakan kolaborasi sebagai penanganan utama.

\section{KESIMPULAN DAN SARAN}

Kanker lidah merupakan kanker dengan prognosis yang jelek dengan angka kematian yang tinggi, sehingga kanker ini akan menimbulkan banyak masalah terutama ketidaknyamanan. Ketidaknyamanan secara langsung akan menurunkan kualitas hidup pasien kanker lidah sehingga perlu mendapatkan perhatian utama. Penerapan comfort theory model dapat membantu perawat dalam memberikan asuhan keperawatan yang holistik dan komprehensif. Pendekatan comfort theory berfokus pada 3 tahap yaitu relief, ease dan transcendence. Perawat spesialis dituntung untuk mampu mengidentifikasi ketidaknyamanan yang tidak terlihat, mengurangi ketidaknyamanan dan meningkatkan kenyamanan dengan menggunakan comfort theory. Pemberian asuhan keperawatan yang holistik dan komprehensif dapat membantu pasien dengan kanker lidah untuk meningkatkan kenyamanan, mengontrol atau mengurangi nyeri serta meningkatkan kualitas hidup

\section{UCAPAN TERIMA KASIH}

Penulis mengucapkan terima kasih kepada semua pihak yang memberikan bantuan serta dukungan sehingga studi kasus ini dapat diselesaikan.

\section{DAFTAR PUSTAKA}

1. Satyan, Breitbart W, Jaramillo J, Chochinov HM. Palliative and terminal care. In: Holland JC (Ed). Textbook of psycho-oncology. New York: Oxford University Press, 2006 : 437-49.

2. Consensus Document For Management Of Tongue Cancer. Anxiety and cancer: the patient and the family. J Clin Psychiatry 2014; 50: $20-25$.

3. Kemenkes RI, 2015. Prevalensi penderita kanker lidah di Indonesia.

4. Mangold, Togerson A, Rogers EM, , et al. Role of human papilloma virus in oral tongue squamous cell carcinoma. Asian Pac J Cancer Prev. 2016; 12(4):889-96.

5. Claudia, Yavuz AA, Ozyilkan O. Cancer cachexia: Pathophysiologic aspects and treatment options. Asia Pacific J Cancer Prev. 2013;8:445-51.

6. Zhang, Couch M, Lai V, Cannon T, Guttridge $\mathrm{D}$, Zanation A, George $\mathrm{J}$, et al. Cancer cachexia syndrome in head and neck cancer patients: Part I. diagnosis, impact on quality of life and survival, and treatment. Head Neck 2012;29:401-11.

7. Mangol, Kelly, Desport JC, Gory-Delabaere G, Blanc-Vincent MP, Bachmann P, Beal J, Benamouzig R, et al. Practice guideline: Standards, options and recommendations for the use of appetite stimulants in oncology. $\mathrm{Br}$ J Cancer 2016;89:S98-100.

8. Desen, Stone, P, Hardy, J, Broadley, K, Tookman, AJ, Kurowska, A, A'Hern, R. 
Fatigue in advanced cancer: a prospective controlled cross-sectional study. Br J Can- cer 2011; 79: 1479-1486

9. Cancer research. Quality of life in terminal care-with special reference to age, gender and marital status. Support Care Cancer 2017; 14: 320-328

10. Cancer treatment centre of america. Multidimensional fatigue and its correlates in hospitalised advanced cancer patients. Eur J Cancer 2017; 43:1030-1036

11. Kimura, Sumi, Sumi T. Fatigue in patients with advanced cancer: a review. Int $\mathbf{J}$ Cancer 2012; 12: 424-428

12. Hibbert, watkinson, gaze wilson, LeGrand, SB. Cancer fatigue-more data, less information? Curr Oncol Rep 2010; 4: 275-279.

13. Rodriguez, Isovsky, C, Schneider, SM. Cancer-related fatigue. Online J Issues Nurs 2003; 8:8. 18 Sood, A, Moynihan, TJ. Cancer-related fatigue: an update. Curr Oncol Rep 2014; 7: 277-282.

14. Suslu, Prue, G, Rankin, J, Allen, J, Gracey, J, Cramp, F. Cancer-related fatigue: a critical appraisal. Eur J Cancer 2013; 42: 846-863.

15. Alves, Bagheri, Shahrokh C., 2011. Cinical Review of Oral and Maxillofacial Surgery, Mosby, Elsevier, Atlanta, Georgia. Hal. 10-12

16. International Association for the Study of Pain. (2017, August 6). IASP Taxonomy. http://www.iasppain.org/Taxonomy

17. Black, Joyce M., \& Hawks, Jane Hokanson. (2014). Keperawatan Mediakl Bedah Manajemen Klinis untuk Hasil yang Diharapkan edisi 8 buku 3. Jakarta: salemba medika.

18. Nanda. (2015). Diagnosis Keperawatan Definisi \& Klasifikasi 2015-2017 Edisi 10 editor $\mathrm{T}$ Heather Herdman, Shigemi Kamitsuru. Jakarta: EGC. 